\title{
Disruption of microbial cells for intracellular products
}

\author{
YUSUF CHISTI and MURRAY MOO-YOUNG* \\ Department of Chemical Engineering, University of \\ Waterloo, Waterloo, Ontario, Canada N2L $3 G 1$
}

\begin{abstract}
Summary. Disintegration of microbial cells is a necessary first step for the production of intracellular enzymes and organelles. With increasing use of intracellular microbial material in industry and medicine, the cell disruption unit operation is gaining in importance.

This review examines the state of the art of the largescale cell disruption technology and disruption methods of potential commercial value.
\end{abstract}

Keywords: Disruption of microorganisms; cell disintegration; intracellular enzymes

\section{Introduction}

The importance of microorganisms as a source of commercially useful chemicals, antibiotics and enzymes has been recognized for a very long time. Nearly all chemicals of microbial origin produced industrially today are of the extracellular type. That is, they are produced within the microbial cell, but are then excreted into the surrounding environment. A much larger proportion of the potentially useful microbial products is retained within the cells. A vast majority of the enzymes known, for example, are intracellular. ${ }^{1}$ Even greater use of microbial products, many of which will be intracellular, can be expected from the predicted surge in biotechnology. ${ }^{2}$

The isolation of intracellular material requires that the

*To whom correspondence should be addressed cell either be genetically engineered so that what would normally be an intracellular product is excreted into the environment, or it must be disintegrated by physical, chemical or enzymatic means to release its contents into the surrounding medium. The genetic manipulation of microbial cells to make them leaky is limited in scope. Making the cell fully permeable to any significant fraction of the intracellular products and enzymes would not only be difficult, but also will imply discontinued existence of the cell. It is in this context that the unit operation of microbial cell disruption for intracellular product isolation will become of increasing importance.

Probably because of the high capital and operating costs of pilot plants for large-scale isolation of intracellular products and the requirement of sizeable teams of scientists and technical staff to obtain meaningful biochemical engineering design data, few studies have been published on the subject. ${ }^{3}$ This review examines the current state of microbial cell disruption technology from an industrial applications point of view. The disruption techniques of potential industrial use are also discussed.

In the last few years several intracellular enzymes have begun to be produced industrially: for example, glucose oxidase for food preservation, penicillin acylase for antibiotic conversion, and asparaginase for possible cancer therapy. ${ }^{4}$ Other examples of intracellular microbial enzymes produced commercially are given in Table 1 .

The necessity of harvesting the producing cells, in order subsequently to extract an internal constitutent, is a major economic disadvantage and, in part, results in the present preoccupation with the manufacture of products of very high value. ${ }^{5}$ Possible cost reductions, however, may be achieved by simultaneous isolation of a number of intracellular products following cell disruption. ${ }^{6}$ This would be even more so if extracellular product isolation preceded the intracellular product isolation from the same fermentation batch.

Table 1 Some examples of intracellular microbial enzymes produced commercially. [Reproduced from Lilly, M. D. in Applied Biochemistry and Bioengineering (Wingard Jr, L. B., Katchalski.Katzir, E. and Goldstein, L., eds) Academic Press, New York, 1979, vol. 2, p. 1 by permission
of Academic Press $\odot$ ]

\begin{tabular}{|c|c|c|}
\hline Enzyme & Source & Examples of use \\
\hline L-Asparaginase (EC 3.5.1.1) & $\begin{array}{l}\text { Erwinia carotovora } \\
\text { Escherichia coli }\end{array}$ & Treatment of acute lymphatic leukaemia \\
\hline Catalase (EC 1.11 .1 .6 ) & Aspergillus niger & Removal of $\mathrm{H}_{2} \mathrm{O}_{2}$ after milk sterilization \\
\hline Cholesterol oxidase (EC 1.1.3.6) & Nocardia rhodochrous & Serum cholesterol analysis \\
\hline$\beta$-Galactosidase (EC 3.2.1.23) & $\begin{array}{l}\text { Kluyveromyces fragilis } \\
\text { Saccharomyces lactis }\end{array}$ & Hydrolysis of lactose in $\mathrm{milk} /$ whey \\
\hline Glucose isomerase (EC 5.3.1.5) & $\begin{array}{l}\text { Bacillus coagulans } \\
\text { Streptomyces } \mathrm{sp}\end{array}$ & Production of high-fructose glucose syrups \\
\hline Glucose oxidase (EC 1.1.3.4) & Aspergilles niger & Serum glucose analysis \\
\hline & Penicillium notatum & Removal of oxygen from foods \\
\hline Glucose-6-phosphate dehydrogenase (EC 1.1.1.49) & Yeast & Clinical analysis \\
\hline Invertase (EC 3.2.1.26) & Saccharomyces cerevisiae & Confectionery \\
\hline Penicillin acylase (EC 3.5 .1 .11 ) & Escherichia coli & Deacylation of benzylpenicillin \\
\hline
\end{tabular}




\section{Cell disruption methods}

Microorganisms are more robust than is generally believed. The resistance to disruption of microorganisms has been referred to by Wimpenny. ${ }^{7}$ He points out that the internal pressure due to osmosis inside an organism such as Micrococcus lysodeikticus or Sarcina lutea is about 20 atmospheres and that the structures responsible for resisting this pressure are about as strong, weight for weight, as reinforced concrete. A variety of disruption methods are available to disintegrate these strong cellular walls and membranes and liberate the cell contents.

A useful classification of the cell disruption methods is given in Figure 1. Only some, mainly mechanical, cell disruption methods have found industrial application. These will be described in more detail in the latter parts of this review. Small-scale techniques used primarily in microbiology and biochemistry laboratory work have been reviewed previously. ${ }^{7-10}$ Some of the earlier work has been reviewed by Aiba and associates. ${ }^{11}$

\section{Mechanical cell disruption}

Both solid shear (e.g. bead mill) and liquid shear (e.g. highpressure homogenizer) based methods of cell disruption have proven successful on a large scale. The solid shear methods may involve either a grinding action as in a ball mill or may involve extrusion of frozen cells, either alone or as a cell-ice (or other abrasive) mixture, through narrow gaps or orifices under high pressure. ${ }^{12}$

Most of the cell disruption equipment in current use was originally designed for the homogenization and size reduction of very different commercial products such as milk and paint. Following Dunnill, ${ }^{6}$ the application of this hardware to cell disruption has been very successful.

\section{Liquid shear methods}

The high-pressure homogenizer. Among the liquid shear disruption devices, the high-pressure Manton-Gaulin APV type homogenizer is probably the most widely used. The technical feasibility of this system for cell disruption was demonstrated by Dunnill and Lilly and their coworkers $^{13}$ and the use of this equipment has been further reported. ${ }^{1,4,6,14-26}$ The high-pressure homogenizer consists of a positive displacement piston pump with one or more plungers. The cell suspension is drawn through a check valve into the pump cylinder and, on the pressure stroke, is forced through an adjustable discharge valve (Figure 2) with restricted orifice. ${ }^{4}$

The disruption of bakers' yeast, Saccharomyces cerevisiae, in an APV Manton-Gaulin homogenizer was examined by Hetherington ${ }^{13}$ and coworkers. The 'knife edge' valve seat (Figure 3) was found to give higher disruption than the 'flat' type unit at the same operating pressure (Figure 4 ). The disruption followed first-order kinetics and could be described by:

$$
\log \left[R_{\mathrm{m}} /\left(R_{\mathrm{m}}-R\right)\right]=k N P^{a}
$$

where $R_{\mathrm{m}}$ is the maximum obtainable protein release after $N$ passes through the valve, $k$ is a dimensional $\left(\mathrm{Pa}^{-a}\right)$ disruption rate constant. The exponent, $a$, on the operating pressure, $P$, had a value of 2.9 . The form of equation (1) was confirmed for disruption of Candida utilis by Engler and Robinson ${ }^{27}$ in a slightly different high-pressure flow device. The value of the exponent, $a$, for an organism is a

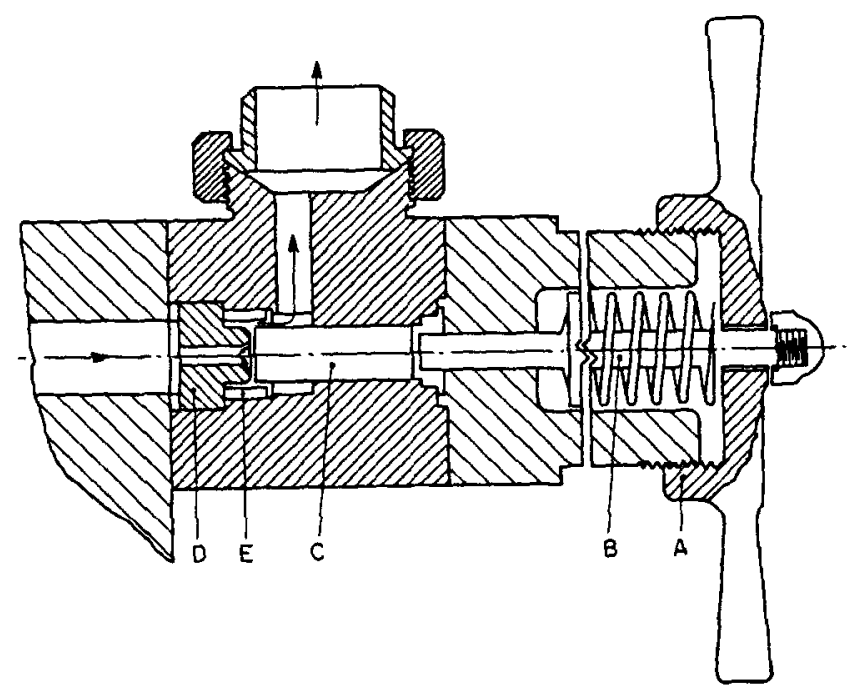

Figure 2 High-pressure homogenizer discharge valve unit. The discharge pressure is controlled by a handwheel assembly, A, which, through a springloaded valve rod, $B$, positions the valve, $C$, in relation to the valve seat, $D$. During discharge, the material passes between the valve and its seat and impinges on an impact ring, $E$. IRedrawn from Hetherington, P. J., Follows, M., Dunnill, P. and Lilly, M. D. Trans. Inst. Chem. Eng. 1971, 49,142 by permission of The Institution of Chemical Engineers $(c)$

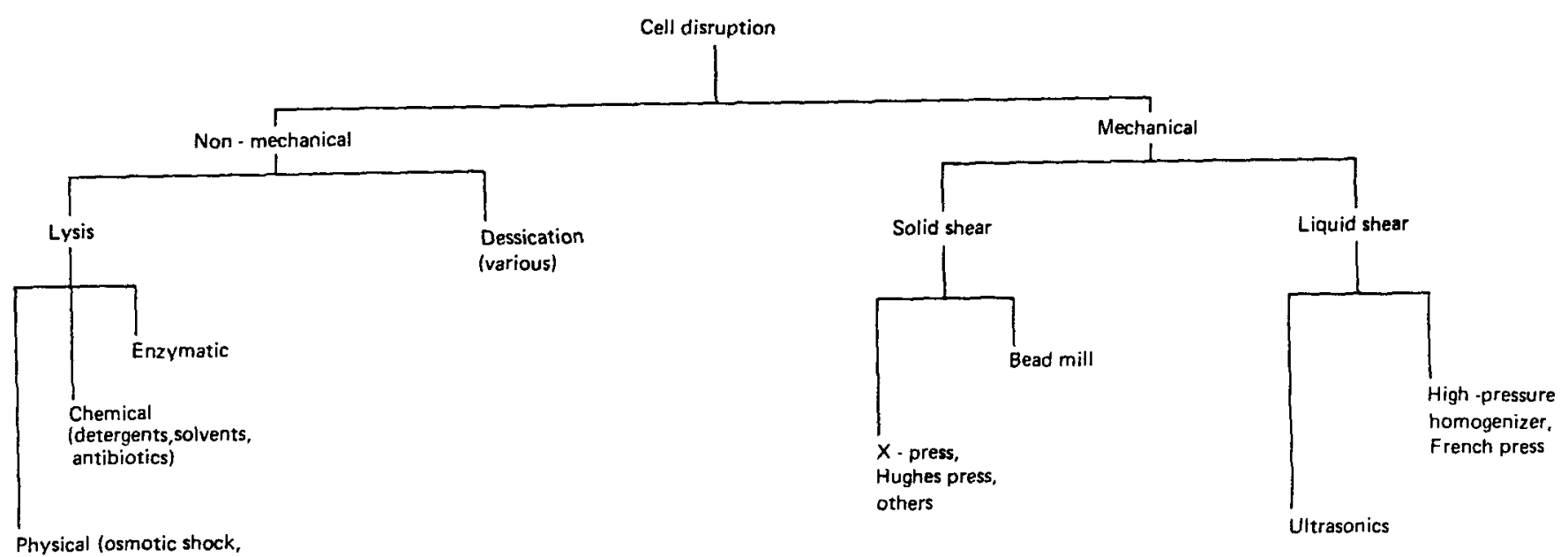

Physical (osmotic shock,

pressure)

Figure 1 Cell disruption methods 


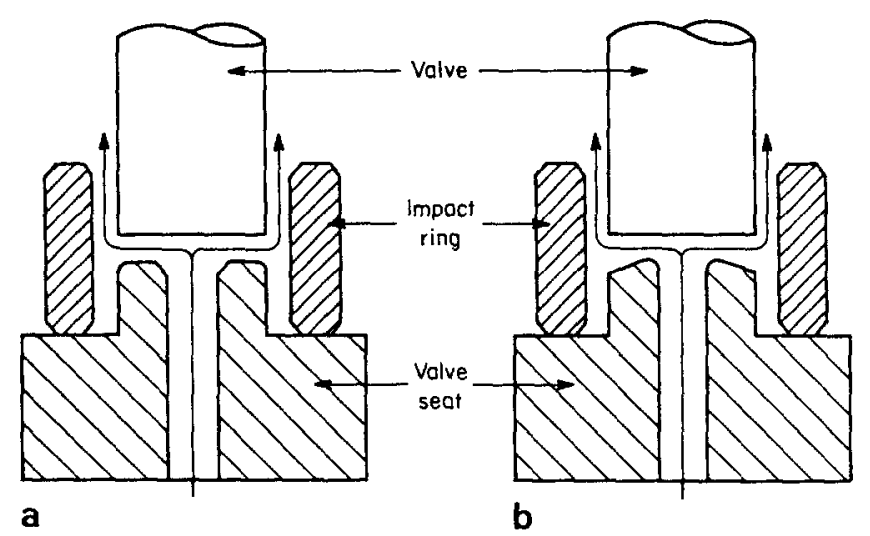

Figure 3 Details of the valve seats. (a) 'Flat' unit. (b) 'Knife-edge' unit. [Redrawn from Hetherington, P. J., Follows, M., Dunnill, P. and Lilly, M. D. Trans. Inst. Chem. Eng. 1971, 49, 142, by permission of The institution of Chemical Engineers (c)

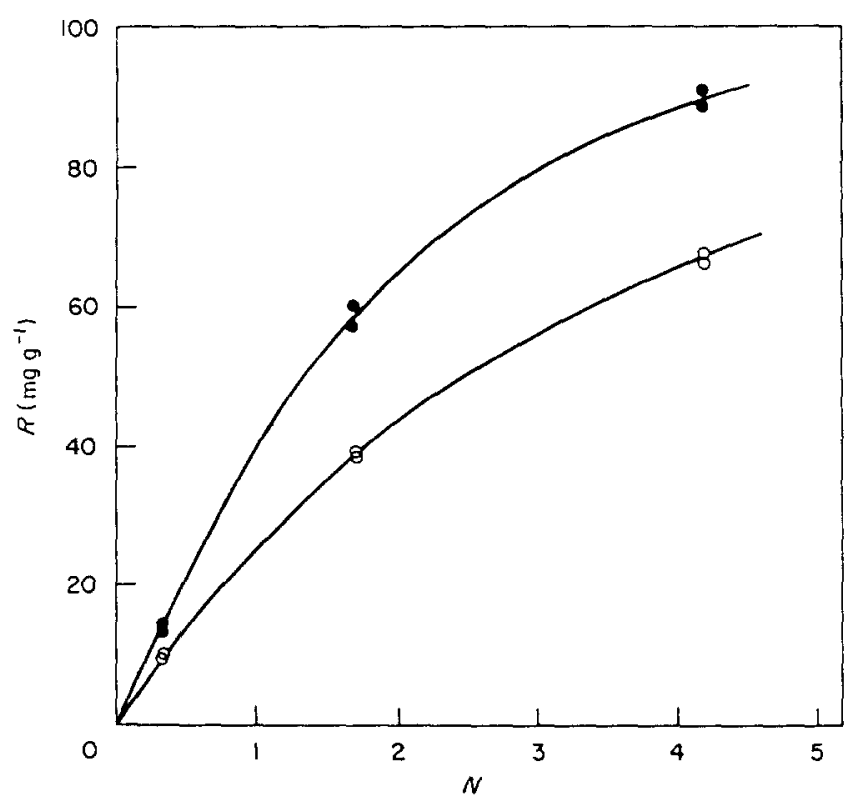

Figure 4 Protein release with different valve seats: 0 , flat; $\bullet$, knife edge. [Redrawn from Hetherington, P. J., Follows, M., Dunnill, P. and Lilly, M. D. Trans. Inst. Chem. Eng. 1971, 49, 142 by permission of The Institution of Chemical Engineers (C)]

measure of its resistance to disruption and is different for different organisms. Thus, for the disruption of Escherichia coli grown on a simple synthetic medium a value of 2.2 has been reported. ${ }^{16}$ For a given organism, $a$ has been found to be dependent on growth history. ${ }^{16,27,28}$ For example, as shown in Figure 5, E. coli cells grown on complex media are more robust than the cells grown on a simple synthetic medium. ${ }^{16}$ The yeast disruption process $^{13}$ was independent of cell concentration over the concentration range of $450-750 \mathrm{~kg}$ yeast $\mathrm{m}^{-3}$ of suspension while the constant, $k$, was temperature dependent and increased with it. Thus, disruption rate increased ${ }^{13}$ by about 1.5 -fold for a change in operating temperature from 5 to $30^{\circ} \mathrm{C}$. Disruption at higher temperatures, however, would be useful only if the desired product is not heat labile. At operating temperatures higher than $40^{\circ} \mathrm{C}$, protein denaturation during disruption has been reported. ${ }^{13}$ Since the temperature rise across a Gaulin homogenizer due to adiabatic compression ${ }^{25}$ is about $2^{\circ} \mathrm{C}$ per $10 \mathrm{MPa}$, inadequate precooling, or failure to cool between multiple passes, can result in temperatures of above $40^{\circ} \mathrm{C}$ and consequent denaturation.

Equation (1) indicates a strong influence of operating pressure on the disruption process. By operating the homogenizer at higher pressures, it should be possible to decrease the number of passes of the cell slurry through the homogenizer for a given degree of disruption. Since the overall throughput rate $(q C / N$, where $q$ is the volume flow rate through the homogenizer $\left(\mathrm{m}^{3} \mathrm{~h}^{-1}\right), C$ is the concentration of yeast slurry ( $\mathrm{kg}$ yeast $\mathrm{m}^{-3}$ suspension), and $N$ is the number of passes) of the homogenizer is inversely dependent on the number of passes, reduced passes would allow increased throughput. Also, the severe downstream clarification problems, ${ }^{13}$ due to the fine cell debris resulting from further disintegration of already disrupted cells on repeated passage through the machine, would be reduced. Note that Hetherington's relationship (equation 1) is valid over a pressure range of 19.6-58.8 MPa for yeast cell slurries with $<750 \mathrm{~kg}$ yeast $\mathrm{m}^{-3}$ suspension. For more concentrated suspensions ( $750 \mathrm{~kg}$ yeast $\mathrm{m}^{-3}$ suspension), this equation breaks down for operating pressures greater than about 29.4 MPa. ${ }^{13}$ An optimal choice of operating pressure is also important because the power consumption during disruption is a linear function of the operating pressure. The power consumption corresponds to about $3.5 \mathrm{~kW}$ per $100 \mathrm{MPa}$ of operating pressure. ${ }^{76}$

The release of about $30 \%$ of the available protein from Candida lipolytica was achieved by Whitworth ${ }^{18}$ in a Manton-Gaulin homogenizer after 6 passes at $55 \mathrm{MPa}$. Protein release did not obey the first order kinetics reported by others. ${ }^{13,27}$ This discrepancy was apparently due to the heterogeneous morphology of $C$. lipolytica which consisted of a mixture of filamentous and elongated-ovoid cells. ${ }^{18}$ Even after repeated passes through the homogenizer, no evidence of protein denaturation was found. A pilot-scale continuous isolation of the intracellular protein and $\beta$ galactosidase from $E$. coli by disruption in a high-pressure homogenizer (Figure 6), with flow rates of up to $0.28 \mathrm{~m}^{3}$ $\mathrm{h}^{-1}$ at an operating pressure of $54 \mathrm{MPa}$, was reported. ${ }^{16,21}$ First-order disruption kinetics were again observed. Using the same equipment, seven intracellular enzymes of bakers'

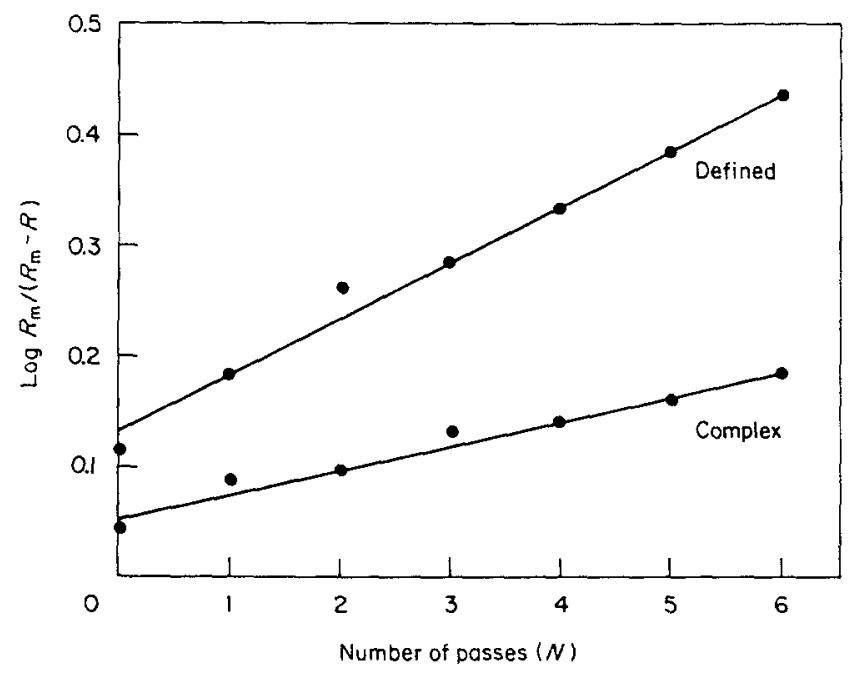

Figure 5 Release of $\beta$-galactosidase from E. coli ML308, grown on defined and complex media, by disruption in a Manton-Gaulin APV homogenizer at $\approx 20 \mathrm{MPa}$. [Redrawn from Gray, P. P., Dunnill, $P$. and Lilly, M. D. in Fermentation Technology Today (Terui, G., ed.) 1972 , p. 347 by permission of The Society of Fermentation Technology, Japan (C)] 
yeast were released. ${ }^{14}$ The release of an enzyme relative to the overall protein release was independent of the disruption pressure, the temperature and the initial yeast concentration. At disruption temperatures of $30^{\circ} \mathrm{C}$ or less, no loss of enzyme activity occurred. Depending on the location of the enzyme activity in the cell, the enzyme release was faster than, equal to, or slower than, the overall protein release (Figure 7).

The continuous isolation of an intracellular aliphatic amidase from Pseudomonas aeruginosa by cell disruption in a high-pressure homogenizer was also described. ${ }^{1}$ A list of 21 large-scale enzyme purification procedures ${ }^{29}$ mentions processes which utilize high-pressure Manton-Gaulin homogenizers to release enzymes from the source cell. The disruption of cells to a state where membrane-bound enzymes are released has been reported ${ }^{20}$ to be more difficult. For example, membrane-bound enzyme cytochrome oxidase from $P$. aeruginosa required three passes at $55 \mathrm{MPa}$ in a high-pressure homogenizer whereas unbound intracellular enzymes could normally be released by a single pass at the same pressure. ${ }^{20}$ Experience gained from cell disruption in high-pressure homogenizers for isolation of intracellular material, and other careful work ${ }^{30,31}$ show that most free enzymes are not susceptible to shear damage to any significant degree in the absence of gas-liquid interfaces. Thus, losses during normal cell disruption may be regarded as negligible, ${ }^{23}$ although it must be appreciated that once the integrity of the cell environment is destroyed, the enzyme may be susceptible to degradation or inactivation by a number of other factors such as proteases. ${ }^{26}$

Membrane-bound enzymes and multienzyme complexes, on the other hand, may be more shear sensitive and less suitable for isolation in a high-pressure flow device. For example, isolation of alkane hydroxylase, a multienzyme membrane-associated complex, by homogenization of Pseudomonas putida is reported to have badly damaged the enzyme. ${ }^{32}$

Although, in addition to yeasts and bacterial cell disruption, the high-pressure homogenizer has been used for the disintegration of mycelial organisms such as Aspergillus niger, ${ }^{4,26,33}$ it has not been found very suitable for this purpose. Problems were encountered ${ }^{26}$ with Aspergillus sp.
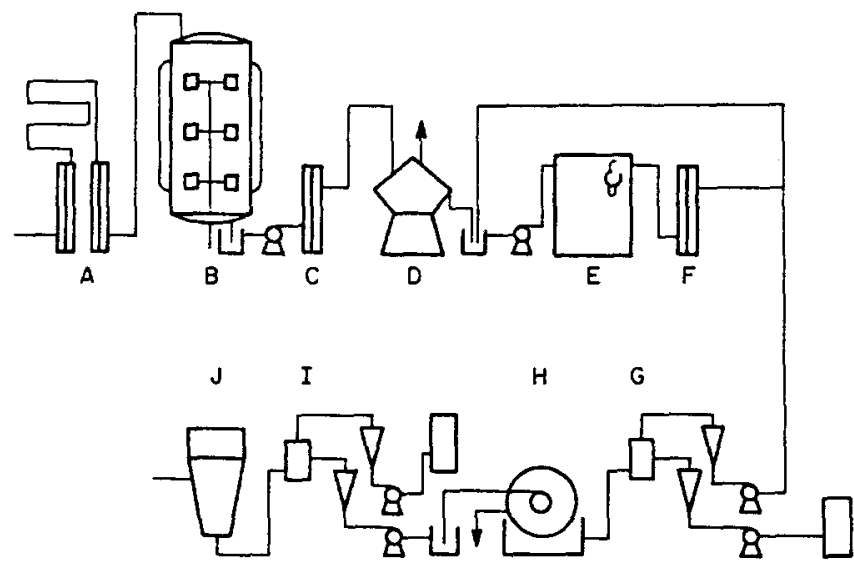

Figure 6 Flow-sheet for the continuous isolation of $\beta$-galactosidase from $E$. coli ML308. A, Continuous flow media sterilizer; $B, 1 \mathrm{~m}^{3}$ fermenter; $C$ and $F$, heat exchangers; $D$, centrifuge; $E$, Manton-Gaulin APV KR3 homogenizer; $G$ and I, mixing chambers; $H$, rotary vacuum filter; $J$, centrifuge. [Redrawn from Gray, $P . P$., Dunnill, P. and Lilly, M. D. in Fermentation Technology Today Terui, G., ed.) 1972, p. 347 by permission of The Society of Fermentation Technology, Japan (c)]
Disruption of microbial ce/ls: Y. Chisti and M. Moo-Young

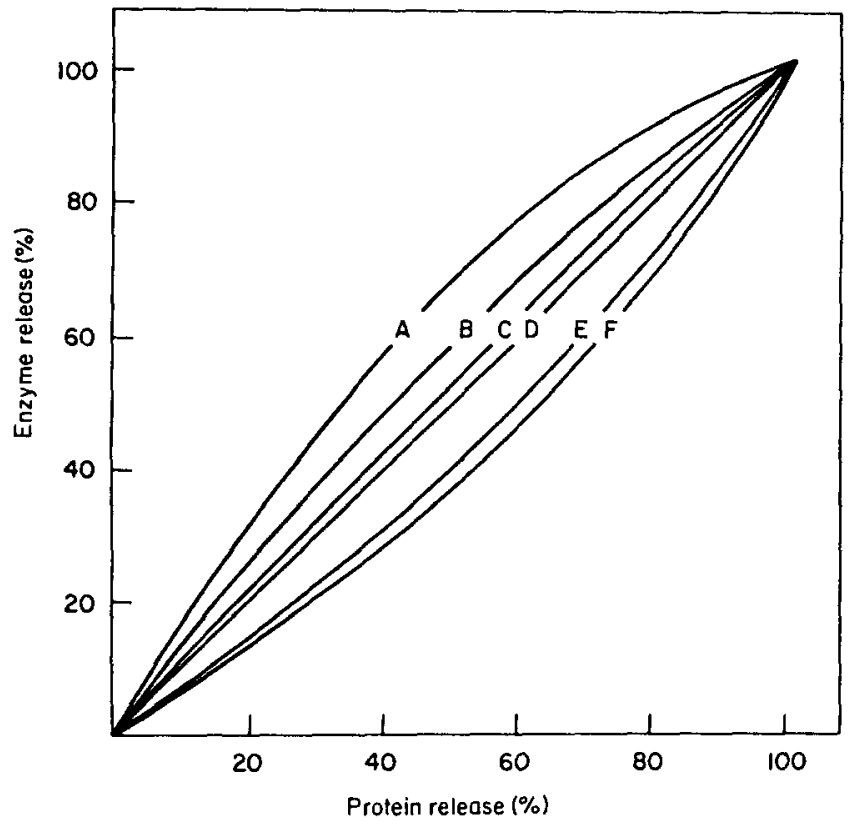

Figure 7 Enzyme release vs, protein release for: $A$, acid phosphatase; $B$, invertase; $C, G 6 P D H$ and $6 P G D H ; D, A D H ; E$, alkaline phosphatase; $F$, fumarase. [Redrawn from Follows, $M$., Hetherington, P. J., Dunnill, P. and Lilly, M. D. Biotechnol. Bioeng. 1971, 13, 549 by permission of John Wiley $\&$ Sons Inc. (]

due to the blockage of the homogenizing valve. Similar problems have been reported by Zetelaki ${ }^{33}$ with $A$. niger where, despite highly diluted cell suspensions, small mycelial pellets gave rise to clogging of the homogenizer valve. In addition, insufficiently high operating pressures have been found to be available ${ }^{26}$ for single-pass disruption of certain filamentous fungi, although multiple passes at lower pressures generally gave satisfactory results.

Large Manton-Gaulin APV homogenizers capable of processing up to $53 \mathrm{~m}^{3} \mathrm{~h}^{-1}$ at $55.2 \mathrm{MPa}$ are available. ${ }^{26}$

Other high shear cell disruption equipment such as the extreme pressure pump ${ }^{34}$ and the French press, ${ }^{35}$ which operate on a similar principle as the Manton-Gaulin APV homogenizer have been described, but have not gained industrial acceptance.

The mechanism of cell disruption in high-pressure flow devices, such as the APV Manton-Gaulin homogenizer, has been the subject of much attention..$^{17,19,27,34,35}$

A careful study ${ }^{17}$ of pressure variation and valve movement in a Manton-Gaulin APV homogenizer, used for disruption of bakers' yeast, was conducted by Brookman with the aim of establishing a mechanism for cell disruption. Turbulence, as a possible cause of disruption, was discounted since variations in cell concentration $(10-80 \%$ $w / v)$ were found to have no significant effect on disruption rate and, also, because the mean suspension velocity through the valve remained constant over a wide pressure range (35-100 MPa). In contrast to Hetherington's equation (equation 1), the pressure drop across the valve, not the operating pressure, was suggested as the main factor in cell disruption. ${ }^{17}$ Further experiments ${ }^{35}$ supported this conclusion, and the influence on cell disruption of the rate at which the pressure drop occurs was revealed. ${ }^{35}$ Thus, measurements made with the valve replaced by various lengths of hypodermic needles showed that, at constant operational pressure $(124 \mathrm{MPa})$, protein release declined with increasing needle length (Figure 8). The more rapid pressure drop may also be the explanation for the observed ${ }^{13}$ 


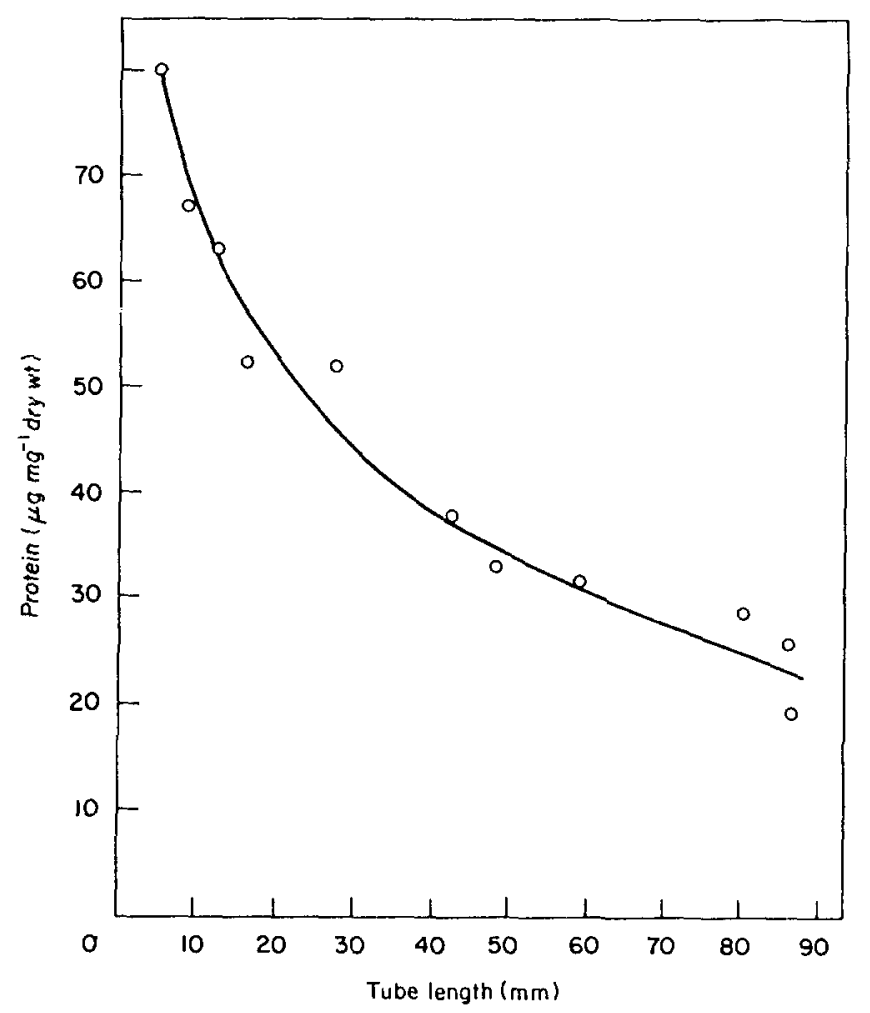

Figure 8 Plot of protein release vs. tube length at constant pressure peak with $60 \%$ w/w yeast suspension at $\mathrm{pH} 7.4$. [Redrawn from Brookman, J. S. G. Biotechnol. Bioeng. 1975, 17, 465 by permis. sion of John Wiley \& Sons Inc. ()]

better performance of the 'knife-edge' valve seat relative to the flat type seat in cell disruption.

Attempts have been made to explain cell disruption on the basis of the hydrodynamics of flow in the valve. ${ }^{19}$ From a consideration of Kolmogoroff's theory, ${ }^{36}$ Doulah and coworkers ${ }^{19}$ derived the theoretical expression :

$$
S_{\mathrm{p}}=1-\exp \left\{-\left[\left(P-P_{0}\right] / \alpha\right]^{\beta}\right\}
$$

where $P_{0}, \alpha$ and $\beta$ are constants, $P$ is the operating pressure, and $S_{\mathrm{p}}$ is the soluble protein release. The values of $\beta$ were found to depend on cell concentration of $S$. cerevisiae, thus contradicting several previous reports (references 13, 14,17 and 27 for example) that cell disruption was independent of concentration. Variation of suspension viscosity with cell concentration and consequent variation in turbulence intensity is the explanation they advanced for their observed concentration dependence of disruption.

In another study of the mechanism of cell disruption in high-pressure flow devices, ${ }^{27}$ experiments were conducted in a high pressure intensifier capable of producing pressures of up to $300 \mathrm{MPa}$ which could be equipped with various outlet nozzles. The equipment handled small volumes $(150 \mathrm{ml})$ of cell suspension in batches. An $80 \mu \mathrm{m}$ i.d. orifice, with and without an impingement plate, was used to study the effect of impingement on cell rupture, while the effect of shear on disruption was investigated by replacing the orifice with capillaries of 102 or $152 \mu \mathrm{m}$ i.d. with lengths varying from 0.026 to $0.150 \mathrm{~m}$. Candida utilis cells grown on a fully defined medium were used in all the experiments. Suspension concentrations ranged from 93 to $148 \mathrm{~kg}$ dry w $\mathrm{m}^{-3}$ and concentration was found to have no significant effect on disruption. The investigators concluded that: 'Impingement of a high velocity jet of suspended cells on a stationary surface is necessary for effective disruption of cell walls in high-pressure flow devices', and that: ${ }^{27}$ 'The rapid release of pressure is not, by itself, an effective means of disrupting the microbial cell walls'. It should be recognized, however, that in a device such as the Manton-Gaulin APV homogenizer the impingement stress is probably directly proportional to the operating pressure.

Ultrasonication. Ultrasonication is another liquid-shear method of disruption which has received some attention in the literature. ${ }^{37-39}$ Ultrasound, sound of frequency higher than $15-20 \mathrm{kHz}$ which is inaudible to the human ear, ${ }^{7}$ is known to cause both inactivation ${ }^{38}$ and, at higher acoustic power inputs, disruption of microbial cells in suspension.

The protein release constant for brewers' yeast sonicated at powers up to 200 acoustic watts at $20 \mathrm{kHz}$ has been shown to be independent of cell concentration up to values of $600 \mathrm{~kg}$ wet $\mathrm{wt} \mathrm{m} \mathrm{m}^{-3}$ and almost proportional to the input acoustic power from 60-195 acoustic watts. ${ }^{4}$ The mechanism of cell disruption by ultrasound is probably associated with the cavitation phenomena associated with ultrasonication. At sufficiently high acoustic power inputs, microbubbles form at various nucleation sites in the fluid. These bubbles grow during the rarefaction phase of the sound wave, and then, in the compression phase, the bubble content is compressed to a minimum radius where the bubble collapses, releasing a violent shock wave which propagates through the medium. This formation, growth and collapse of gas and vapour bubbles owing to the action of intense sound waves is termed cavitation. In the collapse phase of cavitation of bubbles, a large quantity of sonic energy is converted to mechanical energy in the form of elastic waves. The dissipation of this mechanical energy in the fluid suspending the cell has been explained by Doulah $^{39}$ using Kolmogoroff's ${ }^{36}$ theory of local isotropic turbulence. According to Doulah the fluid eddies smaller than the dimensions of a cell will impart motions of various intensities to it, and when the kinetic energy content of a cell exceeds the wall strength, the cell disintegrates. For the disruption of brewers' yeast cells, the theoretical analysis $^{39}$ leads to the expression:

$$
1-S_{\mathrm{p}}=\exp -(k t)
$$

for a given acoustic power input, where $S_{\mathrm{p}}$ is the protein release, $k$ is the protein release constant $\left(\mathrm{min}^{-1}\right)$, and $t$ is the exposure time ( $\mathrm{min}$ ). This expression is identical to that determined experimentally by an independent group ${ }^{40}$ for protein release from a brewers' yeast suspension $(200 \mathrm{~kg}$ wet wt $\mathrm{m}^{-3}$ of suspension) using a self-tuning $20 \mathrm{kHz}$ generator with a capacity of 190 acoustic watts. The dependence of the protein release constant $k$ on acoustic power input was established ${ }^{39}$ to be an exponential one,

$$
k=b\left(p-p_{0}\right)^{0.9}
$$

where $b$ is a constant, $p$ is the power input $\left(\mathrm{J} \mathrm{kg}^{-1} \mathrm{~s}^{-1}\right)$ and $p_{0}$ is the cavitation threshold power. ${ }^{39}$

The absorption of sonic energy by a fluid is dependent on the prevailing pressure, and an increase in the ambient pressure up to a certain limit increases the conversion of sound energy to shock wave energy. ${ }^{41}$ The constant, $k$, is thus pressure dependent. This is confirmed by the obser. vation that an increase in the ambient pressure on cell sus. pensions does indeed lead to enhanced cell disintegration. ${ }^{37}$

Although ultrasonic disintegrators capable of handling up to about $101 \mathrm{~h}^{-1}$ of cell suspension were available as far back as $1967,{ }^{42}$ and large-scale ultrasonic homogenizers are in use in the chemical industry for continuous homogeniza- 
tion of liquid-liquid dispersions and for breaking down agglomerates of powdered particles, ${ }^{43}$ the use of this technique for industrial-scale cell disruption is not practised to our knowledge. There are several reasons for this. Most of the ultrasonication energy absorbed into suspensions ultimately appears as heat, and good temperature control is necessary. Also, the process of ultrasonication is known to give rise to chemical effects ${ }^{39}$ such as the formation of free radicals. The latter, or ultrasound itself, may have damaging influence on some of the molecules of interest. Production of very fine cell debris ${ }^{4}$ occurs and can lead to subsequent processing problems. The difficulty of transmitting sufficient power to large volumes of cell material has been mentioned $;^{26}$ in addition, this method of cell disruption seems less effective for fungal organisms such as $A$. niger. ${ }^{33}$

\section{Solid shear methods}

The bead mill. Cell disruption in bead mills is regarded as one of the most efficient techniques for physical cell disruption. ${ }^{23}$ Various designs of bead mills have been used for microbial cell disruption. ${ }^{15,33,44-55}$ These mills consist of either a vertical or a horizontal cylindrical chamber with a motor-driven central shaft supporting a collection of offcentred discs or other agitating element (Figures 9 and 10). The chamber is filled to the desired level with steel or ballotini glass beads which provide the grinding action. The charge of grinding beads is retained in the chamber by a sieve-plate covering the bottom inlet in vertical machines (Figure 9), while in horizontal units the fluid entry is above the level of the beads in the chamber and no retention mechanism is required (Figure 10). At the fluid exit port, three different types of bead retention systems have been employed: a sieve-plate, a disc rotating in very close proximity to a plate with a central exit port in it (Figure 10) ${ }^{5}$ and a vibrating slot. ${ }^{53,56}$ The latter two types of bead retention devices are said to reduce fouling problems. ${ }^{15,53}$ The horizontal configuration of the mill is known to give a better efficiency of disruption relative to the vertical one. ${ }^{44}$ This is because the upward fluid flow in vertical machines

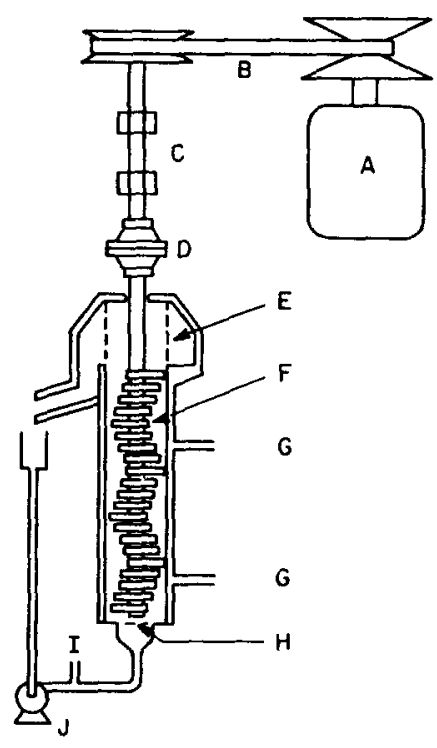

Figure 9 Simplified drawing of the Netzsch-Molinex KE5 agitator mill system: $A$, drive motor; $B$, variable $V$-belt drive; $C$, bearings: $D$, agitator coupling; $E$, cylindrical sieve plate; $F$, agitator discs; $G$, temperature jacket inlet and outlet; $H$, bottom sieve plate; $I$, temperature measuring pocket; $J$, recirculating pump. [Redrawn from Currie, J. A., Dunnill, P. and Lilly, M. D. Biotechnol. Bioeng. 1972, 14, 725 by permission of John Wiley \& Sons Inc. (C)]
Disruption of microbial cel/s: Y. Chisti and M. Moo-Young

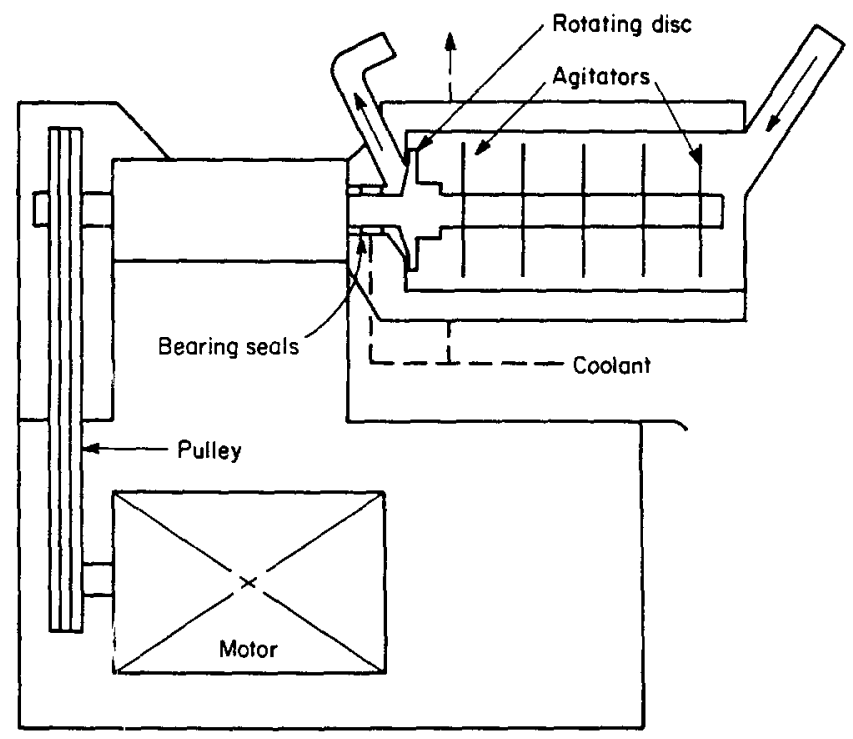

Figure 10 The Dyno Mill. The feed inlet and outlets are above tank level and the rotaiing disc is used to retain beads. [Redrawn from Wang, D. I. C., Cooney, C. L., Demain, A. L., Dunnill, P., Humphrey, A. E. and Lilly, M. D. Fermentation and Enzyme Technology John Wiley, New York, 1979, pp. 238-310 by permission of John Wiley \& Sons Inc. (c)]

tends to fluidize the grinding beads to some degree, thereby reducing grinding efficiency.

Schemes for isolation and purification of the intracellular formate dehydrogenase from $C$. boidinii using disruption of the cells in bead mills have been published, ${ }^{57}$ and a continuous food-feed protein production process involving disruption of $10 \%$ dry weight bakers' yeast and brewers' yeast slurries in a 5 litre nominal capacity bead mill has been reported. ${ }^{49}$ Other similar processes have been discussed in the literature. ${ }^{48,50}$

The kinetics of protein release from bakers' yeast by disruption in a high-speed ball mill have been investigated by Dunnill and Lilly ${ }^{15}$ and depend on the construction of the mill. First-order disruption kinetics have been observed in machines with predominant plug flow, whereas in machines in which the rotor design permits significant backmixing the disruption deviates from the first-order behaviour. ${ }^{15}$ A number of other authors have also reported first-order disruption in bead mills..$^{51,52,54}$ For example, a team of investigators ${ }^{54}$ examined batch and continuous disruption of bakers' yeast in laboratory and pilot scale mills ( 0.6 and 5 litre disruption chamber volumes) and observed first-order kinetics in the batch operation, where the rate of protein release was directly proportional to the amount of unreleased protein:

$$
\mathrm{d} R / \mathrm{d} t=k\left(R_{\mathrm{m}}-R\right)
$$

where $R$ is the weight of protein released per unit weight of packed yeast, $R_{\mathrm{m}}$ is the maximum measured protein release $\left(0.100 \pm 0.005 \mathrm{~kg}\right.$ protein released $\mathrm{kg}^{-1}$ packed yeast $)$. Integration of equation (5) for $t=0$ and $t=t$ (batch time) yields:

$$
\ln \left[R_{\mathrm{m}} /\left(R_{\mathrm{m}}-R\right)\right]=\ln D=k t
$$

where $D$ is the reciprocal of the fraction of unreleased protein.

For continuous disruption, first-order kinetics held, and $D$ could be related to the nature of mixing in the mill expressed in terms of a continuous stirred tank reactor (CSTR) in-series model, ${ }^{54}$ thus:

$$
D=R_{\mathrm{m}} /\left(R_{\mathrm{m}}-R\right)=\left[1+(k \tau / j)^{j}\right]
$$


where $\tau$ is the mean residence time in the mill (total volume of the mill, $V$, divided by the total throughput $q$ ) and $j$ is the number of CSTRs in series; this may include fractions of CSTRs. ${ }^{54}$ The values of $j$ were obtained experimentally from residence time distribution studies.

The disruption rate constant, $k$, is known to be a function of several parameters: temperature, impeller rotational speed, ${ }^{15,51-55}$ bead loading, ${ }^{15,53,55}$ bead size ${ }^{15,51,55}$ and cell concentration. ${ }^{15,55}$

There is evidence ${ }^{54}$ that, within limits, the disruption rate constant, $k$, increases with the agitator tip speed, $U_{\mathrm{t}}$. This variation has been described ${ }^{54}$ by:

$$
k=K U_{\mathrm{t}}
$$

(where $K=0.0036 \mathrm{~m}^{-1}$ for a 0.6 litre mill). Another report $^{55}$ noted that protein release from bakers' yeast increased with agitator tip speed to a limit (Figure 11) beyond which no further increase occurred. Excessively high agitator speeds can lead to significant fragmentation of glass beads. ${ }^{4}$ Such high agitator speeds have not, however, been found necessary. Although increased agitator speeds increase disruption, the amount of heat generated and the power consumed also increase.

The disruption efficiency, $E$, defined ${ }^{54}$ as:

$$
E=R C q / P^{\prime}
$$

where $R$ is the amount of protein released per $\mathrm{kg}$ packed yeast, $q$ the throughput, $C$ the yeast concentration, and $P^{\prime}$ the power consumption for disruption in the 5 litre mill, is shown in Figure 12. From this plot an optimum efficiency can be seen to exist for a given throughput and protein release. At a constant impeller tip speed, the efficiency declines with throughput. This can be explained in the following way: an increase in the longitudinal dispersion or backfiow, and a consequent decrease in the number of effective CSTRs in the mill, will (equation 7) lead to a decrease in the yield of the mill and, hence, a decline in its efficiency. ${ }^{54}$ Thus, whereas the disruption rate constant tends to a maximum value with increasing agitator tip speed (equation 8), the degree of dispersion also increases. The two conflicting effects result in the existence of an optimum disruption efficiency. Equation (7) also shows the influence of mean residence time of the cells in the grinding chamber on disruption. Disruption declines with increased flow rate of the cell slurry through the machine, an observation also reported by several others. ${ }^{46,51,53,55}$ The influ-

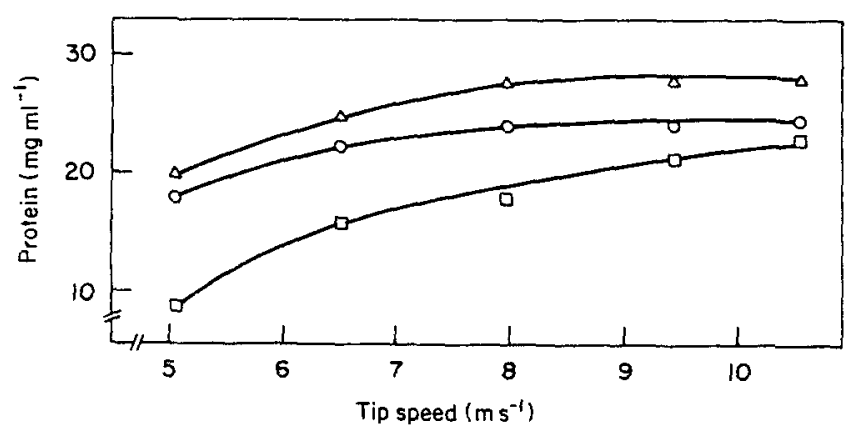

Figure 11 Effect of agitator speed on protein release. The rate of protein release at different agitator tip speeds at bead load volume: $\square, 70 \% ; \triangle, 80 \% ; 0,85 \%$. Constant parameters: bead diameter $0.55-0.85 \mathrm{~mm}$; flow rate of cell slurry, $100 \mathrm{I} \mathrm{h}^{-1}$; cell suspension, $40 \%(w / v)$. [Redrawn from Schütte, H., Kroner, K. H., Hustedt, H. and Kula, M.-R. Enzyme Microb. Technol. 1983, 5, 143]

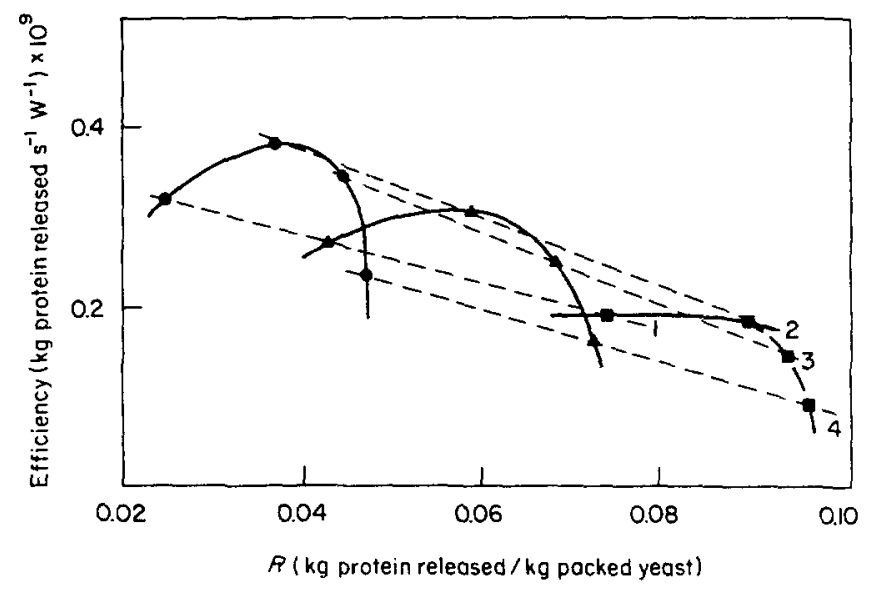

Figure 12 Efficiency of a bead mill at various flow rates and impeller tip speeds. Flow rate $\left(\mathrm{m}^{3} \mathrm{~s}^{-1}\right):-20 \times 10^{-6} ; 4,50 \times 10^{-6}$ -, $100 \times 10^{-6}$. Impeller tip speed: $1,8 \mathrm{~m} \mathrm{~s}^{-1} ; 2,10 \mathrm{~m} \mathrm{~s}^{-1} ; 3,15 \mathrm{~m}$ $\mathrm{s}^{-1} ; 4,20 \mathrm{~m} \mathrm{~s}^{-1}$. [Redrawn from Limon-Lason, J., Hoare, $M$. Orsborn, C. B., Doyle, D. J. and Dunnill, P. Biotechnol. Bioeng. $1979,21,745$ by permission of John Wiley \& Sons Inc. (C)

ence of flow rate, $q\left(\mathrm{~m}^{3} \mathrm{~h}^{-1}\right)$, on the degree of disintegration, $x(\%)$, has been described ${ }^{52}$ according to:

$$
\log [100 /(100-x)]=k / q
$$

where $k$ is a first-order disruption rate constant. The finding that increased flow rate of the cell suspension through the mill reduces the degree of disintegration was confirmed by other experimenters. ${ }^{53}$ For $15 \%$ cell slurries about $90 \%$ disruption of $S$. cerevisiae has been reported ${ }^{53}$ at a residence time of $2.5 \mathrm{~min}$ in a 20 litre nominal capacity mill. Under the same conditions, $84 \%$ of $C$. utilis could be broken. This difference in the degree of disruption of the two organisms is partly due to their different cell sizes, but mainly because of the higher mechanical strength of the cell wall of $C$. utilis. In a similar way, in another report ${ }^{52}$ C. utilis was found to be more resistant to disruption compared to $S$. cerevisiae.

In contrast to cell disruption in the high-pressure homogenizer, Dunnill and Lilly ${ }^{15}$ found that the disruption rate in high-speed ball mills is dependent on yeast concentration between 30 and $60 \%$ packed weight per volume and decreases with increasing cell concentration. Contradicting this are other observations ${ }^{52}$ which indicate no influence of yeast cell concentration (4--20\% dry weight range) on disruption rate

The bead diameter and bead loading in the grinding chamber of the mill are other factors which affect disruption rate constant. Increased bead loading enhances the rate of disruption..$^{15,53,55}$ In a 20 litre Netzsch LME20 industrial bead mill, used ${ }^{55}$ for the release of protein and some enzymes (agitator tip speed of $5.2-10.6 \mathrm{~m} \mathrm{~s}^{-1}$, slurry flow rates of $50-5001 \mathrm{~h}^{-1}$, cell concentrations of $30-$. $50 \% \mathrm{w} / \mathrm{v}, 70-90 \%$ glass bead loading, and $0.45-1 \mathrm{~mm}$ glass bead diameter), increased bead loadings were found to enhance the rate of protein release up to a bead loading of $80 \%$. Further increase in bead load led to a decline in protein release. This latter observation, not reported before, is probably system specific and arises due to inefficient agitation at high bead loadings, possibly due to an insufficiently powerful agitator motor. Temperature increases and power consumption are also strongly influenced by the bead loading, ${ }^{53,55}$ this is shown in Figures 13 and 14 .

The optimum size of the grinding elements, ${ }^{45}$ according 


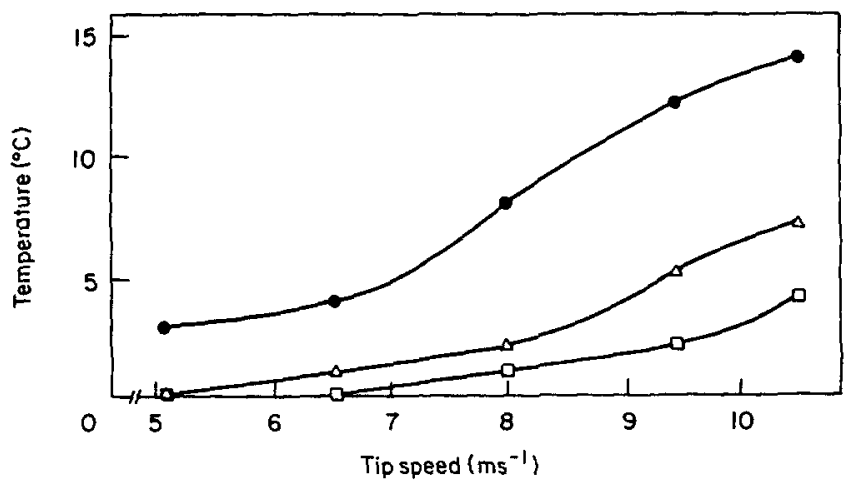

Figure 13 Temperature rise during disruption at bead load volumes: $0,70 \% ; \triangle, 80 \% ; \bullet, 90 \%$. Constant parameters: bead diameter, 0.55-0.85 mm; flow rate, $100 / \mathrm{h}^{-1}$; yeast cell suspension, $40 \% \mathrm{w} / \mathrm{v}$. [Redrawn from Schütte, H., Kroner, K. H., Hustedt, H. and Kula, M.-R. Enzyme Microb. Technol. 1983, 5, 143]

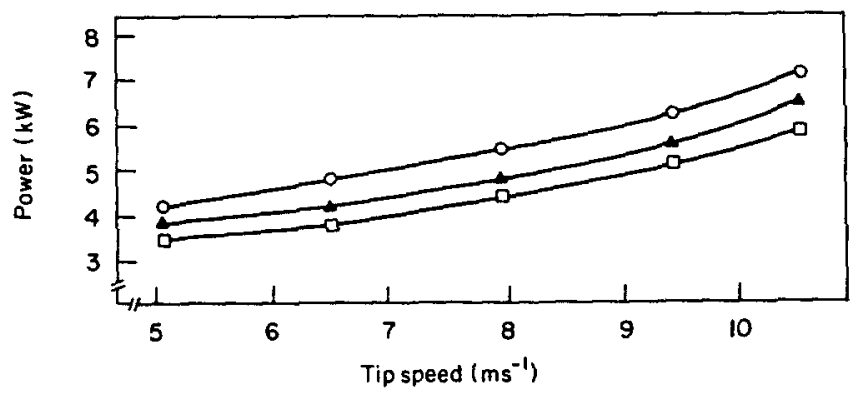

Figure 14 Power consumption of the Netzsch LME20 mill at various tip speeds and bead load volumes: $\square, 70 \% ; \wedge, 75 \% ; 0,85 \%$. Constant parameters: as in Figure 13. [Redrawn from Schütte, H., Kroner, K. H., Hustedt, H. and Kula, M.-R. Enzyme Microb. Technol. 1983, 5, 143]

to Rehacek and Schaefer, ${ }^{53}$ is independent of vessel and agitator configuration. More rapid disruption is achieved with smaller beads; ${ }^{15}$ however, there is an obvious lower limit to the bead size dictated by the bead fluidization and sieve blinding problems encoun tered with very small beads. ${ }^{15}$ Contradicting this is the claim ${ }^{51}$ that increasing bead diameter at first increases the protein release from $S$. carlsbergensis, but protein release declines slightly with a further increase in bead size. This observation remains unexplained. For enzyme release, the location of the desired enzyme in the cell is of importance to the choice of bead diameter and bead loading. ${ }^{55}$ For example, while cytoplasmic enzymes like $D$-glucose-6-phosphate dehydrogenase from yeast cells were solubilized best with $0.55-0.85 \mathrm{~mm}$ glass beads, cell disintegration for $\alpha-\mathrm{D}$-glucosidase isolation was better accomplished with somewhat larger beads of $1 \mathrm{~mm}$ diameter. This observation can be related to the fact that $\alpha$-D-glucosidase is located predominantly in the periplasmic space and complete disintegration of the cells is not necessary to solubilize this enzyme. ${ }^{55}$

In addition to several yeasts ( $S$. cerevisiae, $S$. carlsbergensis, $C$. boidinii, $C$. utilis), a number of bacteria, including E. coli, Bacillus sphaericus, Lactobacillus confusus, Brevibacterium ammoniagenes ${ }^{55}$ and Bacillus subtilis, ${ }^{46}$ have been disrupted in high-speed bead mills. The disintegration of bacteria in a bead mill is hampered by the small dimensions of such cells, ${ }^{55}$ which are approximately $1 / 10$ the size of a yeast cell. Thus, while a 20 litre bead mill was found capable of handling $200 \mathrm{~kg}$ bakers' yeast $\mathrm{h}^{-1}$ with $>85 \%$ disintegration under optimum conditions $\left(1100 \mathrm{rev} \mathrm{min}^{-1}\right.$, at $1001 \mathrm{~h}^{-1}$ and cell concentration of $40 \% \mathrm{w} / \mathrm{v}$ ), only between 10 and $20 \mathrm{~kg} \mathrm{~h}^{-1}$ of bacteria could be processed, depending on the organism. ${ }^{55}$

The performances of a 0.6 litre Dyno-Mill, a 20 litre mill and a Manton-Gaulin homogenizer for the release of leucine dehydrogenase from $B$. sphaericus (Figure 15) have been compared. ${ }^{55}$ While the larger mill and the homogenizer gave similar performances, the smaller mill which used $0.25-0.50 \mathrm{~mm}$ beads gave significantly better enzyme release. ${ }^{55}$ The better performance of the smaller mill is probably due to the smaller bead size used in it.

The work of Schütte and his group, ${ }^{55}$ shown in Table 2,

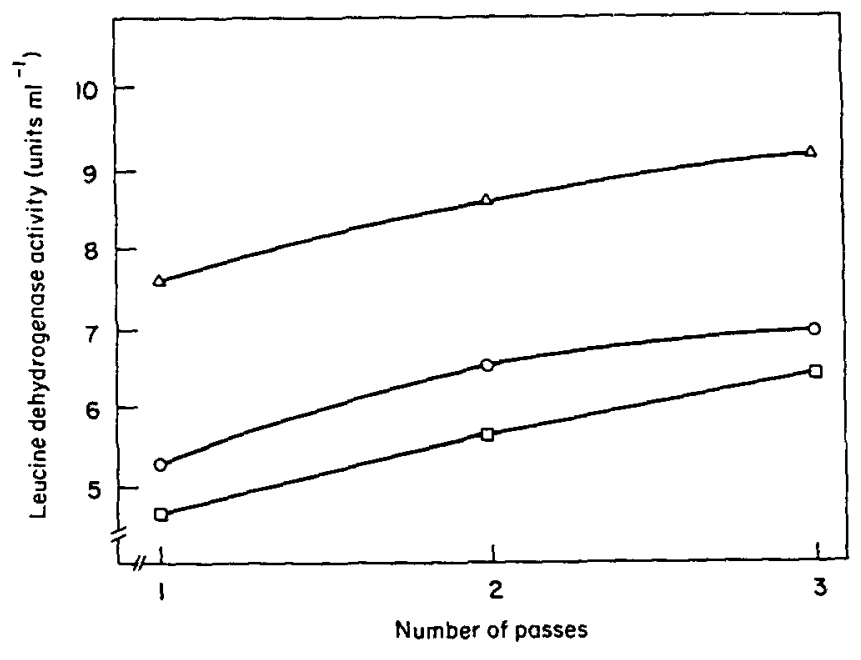

Figure 15 Disruption of Bacillus sphaericus using various types of homogenizers. The release of teucine dehydrogenase activity was followed for three passes in: $\triangle$, Dyno-Mill Type KDL; ${ }^{\circ}$, Netzsch LME20 mill; $\square$, Manton-Gaulin high pressure homogenizer. DynoMill: agitator tip speed, $10 \mathrm{~m} \mathrm{~s}^{-1}$; glass bead diameter, $0.25-0.50$ $\mathrm{mm}$; flow rate, $5 \mathrm{I} \mathrm{h}^{-1}$; bead load volume, $85 \%$; cell suspension, $40 \%$ (w/v). Netzsch LME20 mill: agitator tip speed, $9.5 \mathrm{~m} \mathrm{~s}^{-1}$; glass bead diameter, $0.55-0.85 \mathrm{~mm}$; flow rate, $93 / \mathrm{h}^{-1}$; bead load volume, $80 \%$; cell suspension, $40 \%(w / v)$. Manton-Gaulin: pressure $58.8 \mathrm{MPa}$; flow rate, $541 \mathrm{~h}^{-1} ;$ cell suspension, $40 \%(\mathrm{w} / \mathrm{v})$. [Redrawn from Schütte, H., Kroner, K. H., Hustedt, H. and Kula, M.-R. Enzyme Microb. Technol. 1983, 5, 143]

Table 2 Comparison of the disintegration of various yeasts and bacteria in an industrial bead mill (Netzsch LME 20). [Reproduced from Schütte, H., Kroner, K. H., Hustedt, H. and Kula, M.-R. Enzyme Microb. Technol. 1983, 5, 143]

\begin{tabular}{|c|c|c|c|}
\hline Microorganism & Enzyme analysed & $\begin{array}{l}\text { Activity } \\
\text { solubilized } \\
\langle \%|\end{array}$ & $\begin{array}{l}\text { Number of } \\
\text { passes }\end{array}$ \\
\hline Saccharomyces car/sbergensis & D-Glucose-6 phosphate dehydrogenase & 86 & 1 \\
\hline Saccharomyces cerevisiae & D-Glucose-6 phosphate dehydrogenase & 100 & 1 \\
\hline Candida boidinii & Formate dehydrogenase & 95 & 1 \\
\hline Escherichia coli MRE 600 & Isoleucyl-tRNA synthetase & 95 & 3 \\
\hline Brevibacterium ammoniagenes & Fumarase & 85 & 3 \\
\hline Bacillus sphaericus & Leucine dehydrogenase & 80 & 3 \\
\hline Lactobacillus confusus & Lactate dehydrogenase & 92 & 2 \\
\hline
\end{tabular}


clearly indicates the need for multiple passes through the 20 litre mill for the release of bacterial enzymes. This considerably lowers the equipment capacity for bacterial cell disruption since the flow rate must also be rather low.

Other microorganisms which have been disintegrated in bead mills include algae Scenedesmus obliquus and Spirulina platensis ${ }^{48}$ for intracellular protein, and fungi such as Aspergillus niger. ${ }^{33,46}$ Complete disintegration of $A$. niger in bead mills has been shown to be possible, ${ }^{46}$ and the agitator mill is said to be particularly valuable for disruption of mycelia which can blind the high-pressure homogenizer. ${ }^{1}$ Of a number of disruption methods examined by Zetelaki ${ }^{33}$ for $A$. niger, bead mill distruption was found to be the most effective.

Production of heat due to impacts and friction between the grinding elements is a general problem in agitated mills. ${ }^{53}$ In small mills, a jacketed grinding chamber is generally sufficient to handle the generated heat load. When, however, mills of more than 10 litre capacity are used for substances sensitive to temperatures above $45^{\circ} \mathrm{C}$, cooling through the vessel wall poses serious problems. This problem has been overcome in a 20 litre horizontal industrial bead mill, the Netzsch LM20.5 ${ }^{53}$ This patented ${ }^{58}$ design provides, in addition to a jacketed grinding chamber, a cooled agitator shaft and cooled discs. The discs are mounted on the shaft alternately, radially and obliquely to the shaft (Figure 16). The radial agitator discs impart a radial motion to the grinding elements, while the oblique discs give rise to axial movement of a substantial part of the elements. The crossing of the paths thus achieved gives the mill a very high efficiency. ${ }^{53}$

Thermal and shear denaturation of proteins in bead mills are distinct possibilities. For the release of a number of intracellular enzymes from bakers' yeast in a 5 litre horizontal bead mill, ${ }^{52}$ no denaturation was noticed, however. This is true, in general, at low operation temperatures. In an isolated case, some enzyme inactivation has been reported ${ }^{51}$ even at temperatures as low as $2^{\circ} \mathrm{C}$. In another investigation, ${ }^{54}$ it was found that increasing temperature reduced the measured protein release (Figure 17), apparently due to thermal denaturation and/or modification of physical properties such as suspension viscosity (reduced viscosity at higher temperatures would lead to greater backmixing).

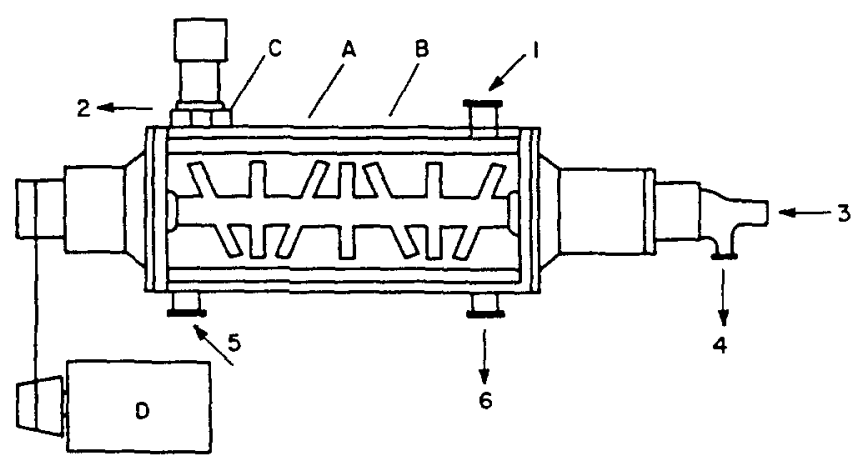

Figure 16 Simplified drawing of the Netzsch model LM20 mill: A, cylindrical grinding vessel with cooling jacket; B, agitator with cooled shaft and discs; $C$, annular vibrating slot separator; D, variable speed drive motor; 1 and 2, product inlet and outlet; 3 and 4 agitator cooling inlet and outlet; 5 and 6 , vessel cooling inlet and outlet. [Redrawn from Rehacek, J. and Schaefer, J. Biotechnol. Bioeng. 1977, 19, 1523 by permission of John Wiley \& Sons Inc. (c)]

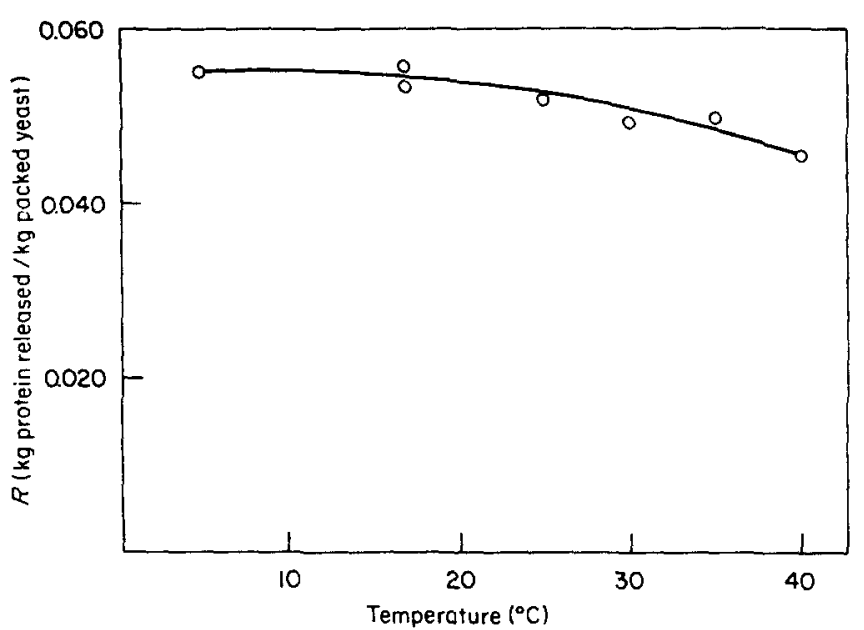

Figure 17 Effect of temperature on the disruption kinetics in a 5 litre mill with stainless steel impellers: $q=0.24 \mathrm{~m}^{3} \mathrm{~h}^{-1}, U_{+}=8 \mathrm{~m}$ $\mathrm{s}^{-1}, C=0.45$. [Redrawn from Limon-Lason, J., Hoare, M., Orsborn, C. B., Doyle, D. J. and Dunnill, P. Biotechnol. Bioeng. 1979, 21, 745 by permission of John Wiley $\&$ Sons Inc. (C)]

The freeze-press. Freeze-pressing of microbial cell suspensions can be used to disrupt the cells. Examples of the freeze-pressing equipment include the Hughes press in which a frozen paste of cells is forced through a narrow slit or orifice, either in the presence of an abrasive at temperatures just below zero or without the abrasive at temperatures of about $-25^{\circ} \mathrm{C} .^{7}$ In the latter case, phase and consequent volume changes of ice contribute to dis. ruption. ${ }^{7,12}$ In addition, solid shear due to crystalline ice is important. According to Wimpenny, ${ }^{7}$ cell breakage in the Hughes press yields cell wall membrane preparations that are relatively intact and may be a good method for isolation of membrane-associated enzymes. A semicontinuous design of X-Press freeze-pressing equipment capable of handling about $10 \mathrm{~kg}$ material every hour has been studied. ${ }^{59}$ For a similar machine, a report ${ }^{60}$ suggests that the device can be scaled up almost unlimitedly. The thermodynamics of compression, and rheology in such devices have received theoretical treatment in a number of papers (e.g. ref. 12). We are not aware of any industrial freeze-pressing equipment commercially available or in use. The reader is referred to other papers ${ }^{12,59,61-65}$ for information on this technique.

\section{Other methods of disruption}

Many other methods of microbial cell disruption exist, but have found no large-scale applications, Osmotic shock, ${ }^{4}$ enzymatic $^{32}$ and chemical lysis ${ }^{22,66}$ are some examples.

Enzymic cell lysis, which is attractive in terms of its delicacy and specificity for just the cell wall structure, is restricted by the $\operatorname{cost}^{25}$ of the enzyme which is lost into the extract. ${ }^{1}$ This can probably be overcome by the use of soluble immobilized enzymes in ultrafilter reactors as described by Dunnill. ${ }^{6}$ Enzymatic cell lysis of $P$. putida using lysozyme has been successful for the isolation of alkane hydroxylase, an enzyme damaged severely during mechanical isolation. ${ }^{32}$ Reduction in the cost of cell lytic enzymes may also be possible by increasing the scale of production, for example. Production of yeast-lytic enzymes from Cytophaga has been carried out on a pilot scale $1.4 \mathrm{~m}^{3}$ fermenter. ${ }^{67-69}$ Cell lytic enzyme production has been examined by Galas et al., ${ }^{70}$ among others. Sensitivity of microorganisms to various lytic enzymes varies 
greatly with the phase of growth and fermentation conditions. ${ }^{28}$ In some cases, autolysis of microbial cells without any foreign enzyme may be possible. Autolysis of Bacillus amyloliquefaciens has been reported. ${ }^{75}$ Although autolysis is, in general, slower than other disruption methods, it is volume independent ${ }^{75}$ and so $100 \mathrm{~m}^{3}$ of cells may be lysed as fast as $100 \mathrm{~cm}^{3}$.

Acids, alkalis, ${ }^{22}$ surfactants ${ }^{71}$ and solvents ${ }^{66}$ have been utilized for cell lysis. Selective extraction of cholesterol oxidase from Nocardia rhedocrous by cell permeabilization, using the surfactant Triton X-100, has been reported. ${ }^{71}$ This surfactant is quite expensive, however, and large-scale use may not be possible. Also, the contamination of the product with the surfactant is another drawback. Other chemicals, such as acids and alkalis, are not very selective and tend to damage sensitive proteins and enzymes along with the cell walls.

Combination disruption methods may prove useful for organisms more resistant to disruption, where mechanical disintegration alone may be costly. ${ }^{25}$ For example, improved protein extractability from $C$. lipolytica was obtained in a high-pressure homogenizer when the cells were suspended in alkaline solutions for a short period prior to homogenization. ${ }^{22}$

\section{Downstream processing}

A cell disruption process cannot be considered in isolation from further downstream processing. This is because the cell disruption operation affects the physical properties of the cell slurry such as viscosity, ${ }^{24}$ density, particle size, and settleability of suspension, ${ }^{22}$ which in turn affect subsequent processing. Changes, in some properties of a $45 \%$ packed weight per volume suspension of bakers' yeast on passage through a Manton-Gaulin APV homogenizer at $49 \mathrm{MPa}$ and $5^{\circ} \mathrm{C}^{24}$ are shown in Figure 18. Homogenized cell suspensions have been found to be more stable. ${ }^{22}$ Sedimentation of mechanically disrupted cell suspensions in industrial centrifuges has been studied ${ }^{24}$ and a report ${ }^{72}$ on clarification of these suspensions via rotary vacuum precoat filtration exists. These studies indicate the need for the choice of appropriate cell disruption equipment, and for the extent of treatment in an equipment, in order

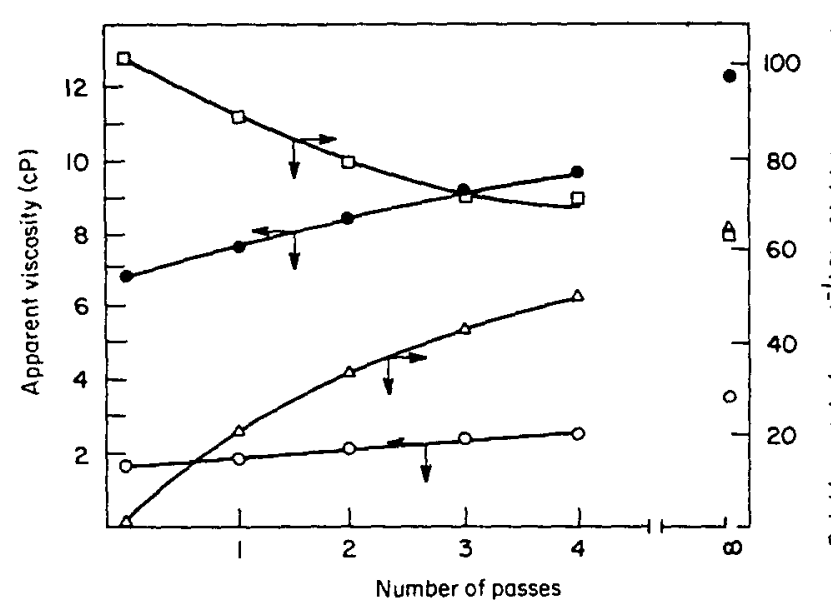

Figure 18 Changes in the properties of yeast suspensions during disruption. •, Apparent viscosity of the suspension at $217 \mathrm{~Hz} ; 0$, apparent viscosity of suspension supernatant at $217 \mathrm{~Hz}$; 0 , packed solid content of suspension; $\Delta$, soluble protein in the suspension supernatant. [Redrawn from Mosqueira, F. G. Higgins, J. J., Dunnill, P. and Lilly, M. D. Biotechnol. Bioeng. 1981, 23, 335 by permission of John Wiley \& Sons Inc. (c)]
Disruption of microbial cells: Y. Chisti and M. Moo-Young

to facilitate downstream processing of the disrupted material.

\section{Biosafety in cell disruption}

In most treatments of bioprocesses, the process safety tends to be ignored. This is also true of the microbial cell disruption operations. Some safety considerations in the disruption of pathogenic organisms in industrial equipment such as the Manton-Gaulin APV homogenizer and in ball mills have been treated in the literature. ${ }^{73}$ The possibility of gasket failure in high-pressure devices and consequent formation of a jet of partly disrupted cell suspension indicates the need for appropriate enclosures. ${ }^{73}$ The operational safety of some cell disruption machines has also been discussed by Dunnill. ${ }^{3}$

\section{Conclusions}

For large-scale cell disruption, the mechanical methods of disruption are seemingly the most popular. Of these, the high pressure homogenizer and the bead mill are the most commonly used. The high-pressure homogenizer is best suited for some bacteria and yeasts, while the bead mill appears more suitable for the disintegration of yeast cells and for mycelial organisms and algae. There is enough evidence to show that the mechanical cell disruption methods do not damage most intracellular enzymes and proteins; membrane-associated enzymes and multienzyme complexes may be the exceptions.

Other techniques which may have potential large-scale applications are ultrasonication, freeze-pressing and enzymatic lysis. A combination of two or more disruption techniques for disruption of more resistant organisms may have economic advantages.

The finding that fermentation conditions influence the resistance of microbial cells to disruption should be further investigated and could be favourably used to manipulate the ease of disruption of a cell. Studies of disruption kinetics and of the influence of cell morphology on kinetics of disintegration are needed; and very little information is available on disruption of mycelial organisms.

\section{Nomenclature}

\section{a Exponent on $P$}

$\mathrm{ADH}$ Alcohol dehydrogenase

$b \quad$ A constant

$C \quad$ Concentration of microbial cells in suspension

$D=\quad=R_{\mathrm{m}} /\left(R_{\mathrm{m}}-R\right)$, inverse of the fraction of unreleased protein

$E \quad=R C q / P^{\prime}$, disruption efficiency

G6PDH Glucose-6-phosphate dehydrogenase

$j \quad$ Number of CSTRs in series

$K \quad$ A constant

$k \quad$ Disruption rate constant

$N \quad$ Number of passes through the homogenizer

$P \quad$ Operating pressure

$P_{0} \quad$ A constant

$P^{\prime} \quad$ Power consumption

$p \quad$ Acoustic power input

$p_{0} \quad$ Cavitation threshold power

$q \quad$ Volume flow rate

$R \quad$ Protein release after $N$ passes

$R_{\mathrm{m}} \quad$ Maximum obtainable protein release

$S_{\mathrm{p}} \quad$ Soluble protein release 
$t \quad$ Time, batch time, exposure time

$U_{\mathrm{t}} \quad$ Agitator tip speed

$V \quad$ Volume of the mill

$x \quad$ Degree of disintegration (\%)

6PGDH 6-Phosphogluconate dehydrogenase

\section{Greek symbols}

$\begin{array}{ll}\alpha & \text { A constant } \\ \beta & \text { A constant } \\ \tau & \text { Mean residence time in the mill }\end{array}$

\section{References}

1. Dunnill, P. and Lilly, M.D. Biotechnol. Bioeng. Symp. 1972, 3 , 97

2 Humphrey, A. E. Chem. Eng. Prog. December 1984, p. 7

3 Dunnill, P. Chem. Ind. (London) 20 November 1982, p. 877

4 Wang, D. I. C., Cooney, C. L., Demain, A. L., Dunnill, P., Humphrey, A. E. and Lilly, M. D. Fermentation and Enzyme Technology John Wiley, New York, 1979, pp. 238-310

5 Kirsop, B. H. Chem. Ind. (London) 4 April 1981, p. 218

6 Dunnill, P. in Fermentation Technology Today (Terui, G., ed.), Society of Fermentation Technology, Japan, 1972, pp. 187

7 Wimpenny, J. W. T. Process Biochem. 1967, 2 (7), 41

8 Wiseman, A. Process Biochem. 1969, 4 (5), 63

9 Hughes, D. E., Wimpenny, J. W. T. and Lloyd, D. in Methods in Microbiology (Norris, J. R. and Ribbons, D. W., eds), Academic Press, London, 1971, vol. 5B, p. 1

10 Coakley, W. T., Bater, A. J. and Lloyd, D. Adv. Microb. Physiol. 1977, 16, 279

11 Aiba, S., Humphrey, A. E. and Millis, N. F. Biochemical Engineering 2nd edn, Academic Press Inc., New York, 1973, pp. 358-362

12 Scully, D. B. and Wimpenny, J. W. T. Biotechnol. Bioeng. $1974,16,675$

13 Hetherington, P. J., Follows, M., Dunnill, P. and Lilly, M. D. Trans. Inst. Chem. Eng. 1971, 49, 142

14 Follows, M., Hetherington, P. J., Dunnill, P. and Lilly, M. D. Biotechnol. Bioeng. 1971, 13,549

15 Dunnill, P. and Lilly, M. D. in Single-Cell Protein II (Tannenbaum, S. R. and Wang, D. I. C. eds), The MIT Press, Cambridge, 1975 ,p. 179

16 Gray, P. P., Dunnill, P. and Lilly, M. D. in Fermentation Technology Today (Terui, G., ed.), Society of Fermentation Technology, Japan, 1972, p. 347

17 Brookman, J. S. G. Biotechnol. Bioeng. 1974, 16, 371

18 Whitworth, D. A. Biotechnol. Bioeng. 1974, 16, 1399

19 Doulah, M. S., Hammond, T. H. and Brookman, J. S. G. Biotechnol. Bioeng. $1975,17,845$

20 Melling, J, and Phillips, B. W. in Handbook of Enzyme Biotechnology (Wiseman, A., ed.), Ellis Horwood, Chichester, 1975 , p. 181 ; ibid. p. 58

21 Higgins, J. J., Lewis, D. J., Daly, W. H., Mosqueira, F. G. Dunnill, P. and Lilly, M. D. Biotechnol. Bioeng. 1978, 20, 159

22 Cherl-Ho Lee, Shek Kwan Tsang, Rintaro Urakabe and Cho Kyun Rha Biotechnol. Bioeng. 1979, 21, 1

23 Darbyshire, J. in Topics in Enzyme and Fermentation Biotechnology (Wiseman, A., ed.), Ellis Horwood, Chichester, 1981 , vol. 5, p. 147

24 Mosqueira, F. G., Higgins, J. J., Dunnill, P. and Lilly, M. D. Biotechnol. Bioeng. 1981, 23, 335

25 Becker, T., Ogez, J. R. and Builder, S. E. Biotechnol. Adv. 1983,1 (2), 24

26 Lambert, P. W. in The Filamentous Fungi (Smith, J. E., Berry, D. R. and Kristiansen, B, eds), Edward Arnold, London, 1983 , vol. 4 , p. 210

27 Engler, C. R. and Robinson, C. W. Biotechnol. Bioeng. 1981, 23,765

28 Fish, N. M. and Lilly, M. D. Biotechnology 1984, 2,623

29 Scawen, M. D., Atkinson, A and Darbyshire, J.Applied Protein Chemistry (Grant, R. A., ed,), Applied Science Publishers, London, 1980 , pp. $281-324$

30 Thomas, C. R., Nienow, A. W. and Dunnill, P. Biotechnol. Bioeng. 1979, 21, 2263

31 Thomas, C. R., and Dunnill, P. Biotechnol. Bioeng. 1979 , 21, 2279

32 Fish, N. M., Harbron, S., Allenby, D. J. and Lilly, M. D. Eur. J. Appl. Microbiol. Biotechnol. 1983, 17 (1), 57
33 Zetelaki, K. Process Biochem. 1969, 4 (12), 19

34 Brookman, J. S. G. and Davis, M. Biotechnol. Bioeng. 1973, 15,693

35 Brookman, J. S. G. Biotechnol. Bioeng. 1975, 17, 465

36 Kolmogoroff, A. N. C. R. Acad. Sci. URSS 1941, 30, 301; ibid. $1941,32,16$

37 Neppiras, E. A. and Hughes, D. E. Biotechnol. Bioeng. 1964, 6, 247

38 Dakubu, S. Biotechnol. Bioeng. 1976, 18, 465

39 Doulah, M. S. Biotechnol. Bioeng. 1977, 19, 649

40 James, C. J., Coakley, W. T. and Hughes, D. E. Biotechnol. Bioeng. 1972, 14, 33

41 Agranat, B. A. and Bashkirov, V. I. Sov. Phys. Dokl. 1968 13,328

42 Dunnill, P. and Lilly, M. D. Process Biochem. 1967, 2 (7), 13

43 Grange, A. 4th European Conference on Mixing Leeuwenhorst, 27-29 April 1982, p. 423, poster ii

44 Rehacek, J., Beran, K. and Bicik, V. Appl. Microbiol. 1969 17,462

45 Rehacek, J. in Disintegration von Mikroorganismen WAB, Basle, 1970

46 Rehacek, J.Experientia 1971, 27, 1103

47 Currie, J. A., Dunnill, P. and Lilly, M. D. Biotechnol. Bioeng. $1972,14,725$

48 Hedenskog, G. and Ebbinghaus, L. Biotechnol. Bioeng. 1972, 14,447

49 Hedenskog, G. and Morgan, H. Biotechnol. Bioeng. 1973, 15, 129

50 Machek, F., Fencel, Z., Beran, K., Behlova, B., Sillinger, V. and Kejmar, J. Biotechnol. Bioeng. Symp. 1974, 4, 977

51 Marffy, F. and Kula, M.-R. Biotechnol. Bioeng. 1974, 16, 623

52 Mogren, H., Lindblom, M. and Hedenskog, G. Biotechnol. Bioeng. 1974, 16, 261

53 Rehacek, J. and Schaefer, J. Biotechnol. Bioeng. 1977, 19 1523

54 Limon-Lason, J., Hoare, M., Orsborn, C. B., Doyle, D. J. and Dunnill, P. Biotechnol. Bioeng. 1979, 21, 745

55 Schütte, H., Kroner, K. H., Hustedt, H. and Kula, M.-R. Enzyme Microb. Technol. 1983, 5, 143

56 Bicik, V. and Kasper, J. US Pat. 3904 133, (1974)

57 Kroner, K. H., Schütte, H., Stach, W. and Kula, M.-R. presented at The Second European Congress of Biotechnology 5-10 April 1981, Eastbourne

58 Bicik, V. and Kasper, J. US Pat. 3993254 (1974)

59 Magnusson, K.-E. and Edebo, L. Biotechnol. Bioeng. 1976, 18,975

60 Heden, C.G. Biotechnol. Bioeng. Symp. 1974, 4, 1003

61 Edebo, L. J. Biochem. Microbiol. Technol. Eng, 1960, 2 , 453

62 Edebo, L. Biotechnol. Bioeng. 1966, 8, 461

63 Edebo, L. and Magnusson, K. E. Biotechnol. Bioeng, Symp. $1974,4,863$

64 Magnusson, K.E. and Edebo, L, Biotechnol. Bioeng. 1976 18,865

65 Magnusson, K.-E. and Edebo, L. Biotechnol. Bioeng. 1976 18,449

66 Gray, P. P., Dunnill, P. and Lilly, M. D. I. Ferment. Technol. $1972,50,381$

67 Asenjo, J. A. Advances in Biotechnology (Moo-Young, M. ed.), Pergamon Press, Toronto, 1981, vol. 3, p. 295

68 Asenjo, J. A., Dunnill, P. and Lilly, M. D. Biotechnol. Bioeng. $1981,23,97$

69 Asenjo, J. A. and Dunnill, P, Biotechnol. Bioeng. 1981, 23, 1045

70 Galas, E., Bielecki, S., Antczak, T., Wieczorek, A., and Blaszczyk, R. in Advances in Biotechnology (Moo-Young, M., ed.), Pergamon Press, Toronto, 1981, vol. 3, p. 301

71 Buckland, B. C., Lilly, M. D. and Dunnill, P. Biotechnol. Bioeng. 1976, 18,601

72 Gray, P. P., Dunnill, P. and Lilly, M. D. Biotechnol. Bioeng. $1973,15,309$

73 Harris-Smith, R. and Evans, C. G. T. Biotechnol. Bioeng. Symp. 1974, 4, 837

74 Lilly, M. D. in Applied Biochemistry and Bioengineering (Wingard Jr, L. B., Katchalski-Katzir, E. and Goldstein, L., eds), Academic Press, New York, 1979, vol. 2, p. 1

75 Cumming, R. H., Tuffnell, J. and Street, G. Biotechnol. Bio. eng, 1985, 27,887

76 Kula, M.-R. in Biotechnology (Rehm, H.-J. and Reed, G. eds), VCH, Weinheim, 1985, vol. 2, p. 725 